УДК 697.329:621.577.22

\title{
ЧИСЕЛЬНА МОДЕЛЬ РОБОТИ ГОРИЗОНТАЛЬНОГО ГРУНТОВОГО КОЛЕКТОРА ТЕПЛОНАСОСНОЇ УСТАНОВКИ
}

\author{
Басок Б. І., член-кореспондент НАН України, Недбайло О.М., канд. тех. наук, Божко І.К. \\ Інститут технічної теплофізики НАН України, вул. Желябова, 2а, Київ, 03680, Україна
}

В роботі представлено розроблену в Інституті технічної теплофізики Національної академії наук України теплофізичну чисельну модель для дослідження процесів гідродинаміки та теплообміну в горизонтальному грунтовому колекторі неглибокого залягання. Наведено результати верифікації даної моделі та розраховані основні енергетичні показники роботи грунтового колектора.

В работе представлена разработанная в Институте технической теплофизики Национальной академии наук Украины теплофизическая численная модель для исследования процессов гидродинамики и теплообмена в горизонтальном грунтовом коллекторе неглубокого залегания. Приведены результаты верификации данной модели и рассчитаны основные энергетические показатели работы грунтового коллектора.

Бібл. 10, рис. 7.

The paper presents a thermophysical numerical model developed at the Institute of Technical Thermophysics of the National Academy of Sciences of Ukraine for studying the processes of hydrodynamics and heat transfer in a shallow horizontal horizontal collector. The results of verification of this model are given and the main energy indicators of the ground collector operation are calculated.

Ключові слова: горизонтальний грунтовий колектор; теплонасосна установка; система теплопостачання.

Постановка проблеми. Оскільки акумульована теплота сонячної радіації обмежується шаром грунту товщиною не більше $6 . .10$ м, для іiі вилучення 3 метою подальшого використання для потреб систем опалення та гарячого водопостачання, найбільш перспективними є системи з використанням горизонтальних грунтових колекторів неглибокого закладення. До таких відносяться змієвикові трубні системи, які розміщуються на глибині $h=1,2 \ldots 1,6$ м 3 кроком між трубами $L=0,5 \ldots 1,5$ м.

Аналіз основних досліджень та публікацій. Як показав аналіз літературних джерел, в них недостатньо висвітлено питання теоретичних та експериментальних досліджень горизонтальних грунтових теплообмінників неглибокого залягання, які використовуються в якості низькопотенційних джерел теплової енергії для теплових насосів. В основному, наводяться тільки результати математичного моделювання роботи цих колекторів. При цьому, описуються моделі [1 - 5], які орієнтовані на певний тип грунту та конструкцію теплообмінника.

Формулювання мети статmі. Основною метою статті $\epsilon$ теоретичні та експериментальні дослідження гідродинаміки та теплообміну в низькотемпературному грунтовому контурі теплонасосної системи $\mathrm{i}$, на їх основі, розробка та впровадження теплонасосних систем теплопостачання для енергоефективних будинків.

Основна частина. В даний час широкого поширення набули теплонасосні установки, призначені для вилучення низкопотенційної теплоти з грунту з подальшим ïi використанням для систем автономного опалення, гарячого водопостачання та кондиціонування приміщень будівель різного призначення. Важливим елементом таких установок $є$ горизонтальний грунтовий колектор, ефективність роботи якого значно впливає на теплонасосну установку [6 - 9]. Горизонтальний колектор являє собою плоский змійовик, розташований в траншеях, в якому циркулює теплоносій. Перевагою грунтових колекторів неглибокого закладення є природне відновлення в теплий період (за рахунок сонячної інсоляції / або при пасивному кондиціонуванні) температурного стану грунтового масиву після експлуатації теплонасосної установки в опалювальний період.

Одним 3 важливих умов ефективної роботи грунтового колектора, як теплообмінного пристрою, $\epsilon$ раціональний вибір його конструкційних параметрів, таких як загальна довжина трубопроводу, діаметр труби, відстань між осями сусідніх труб змійовика, глибина закладення і т. п. Оптимальні величини даних параметрів можуть бути отримані на основі варіантних розрахунків теплових режимів колекторів при різних значеннях зазначених величин.

Задача про температурний стан грунтового масиву при роботі грунтового колектору формулюється в такий спосіб. Розглядається теплоперенос в прямокутному паралелепіпеді зі сторонами $x_{\max }, y_{\max } \mathrm{i} z_{\max }$, що охоплює ділянку грунтового масиву. На глибині $h$ розглянутої ділянки розташовується горизонтальний плоский трубчастий змієвиковий теплообмінник (грунтовий колектор) 3 циркулюючим теплоносієм. Значення $x_{\max }$, $y_{\max }$ i $z_{\max }$, вибираються так, щоб процеси теплопереносу до грунтового колектора в мінімально впливали на температурні умови на межі розрахункової області. Температурне поле грунтового масиву описується рівнянням теплопровідності:

$c_{2} \rho_{2} \frac{\partial T_{2}}{\partial \tau}=\frac{\partial}{\partial x}\left(\lambda_{2} \frac{\partial T_{2}}{\partial x}\right)+\frac{\partial}{\partial y}\left(\lambda_{2} \frac{\partial T_{2}}{\partial y}\right)+\frac{\partial}{\partial z}\left(\lambda_{2} \frac{\partial T_{2}}{\partial z}\right)$.

Для його вирішення на поверхні грунту $(z=0)$ 
повинні бути задані граничні умови, що залежать від кліматичних характеристик місцевості і ряду метеорологічних факторів. У загальному випадку це можуть бути умови першого або третього роду:

$$
\begin{aligned}
& T_{2}(\tau, 0, y, x)=T_{0}(\tau, 0) . \\
& -\left.\lambda_{2} \frac{\partial T_{2}}{\partial z}\right|_{z=0}=\alpha_{a}\left[T_{2}(\tau, 0, y, x)-T_{a}(\tau)\right] .
\end{aligned}
$$

Представлені умови відображають характер теплового взаємодії грунту з повітряним середовищем, температура якого постійно змінюється. У природних умовах коливання температури зовнішнього повітря, а також інтенсивності радіаційного теплообміну призводять до зміни не тільки температури поверхні грунту $T_{0}(\tau, 0)$, а й до змін закону розподілу температури по його глибині $T_{0}(\tau, z)$. Але зазначені зміни спостерігаються лише до певної глибини, нижче якої температуру грунту можна умовно вважати однаковою і незалежною від клімату довкілля. Якщо межа розрахункової області виявляється нижче вказаного рівня, то умова на нижній межі $\left(z=-z_{\max }\right)$ можна наближено вважати умовами теплоізоляції:

$$
\left.\frac{\partial T_{2}}{\partial z}\right|_{z=-z_{\max }}=0 .
$$

На інших границях розрахункової області задаються умови, що відповідають температурному режиму грунтового масиву при відсутності колектора. Якщо теплоперенос в масиві, що пов'язаний з роботою колектора, відсутній, то розподіли температури в горизонтальних перетинах масиву будуть рівномірними. Це означає, що часткові похідні від температури $T 2$ по змінним $x$ або $у$ будуть дорівнювати нулю. Можна припустити, що зазначені умови приблизно виконуються на бічних границях розрахункової області при роботі колектора, якщо ці границі досить віддалені від його крайніх сегментів. В цьому випадку:

$$
\left.\frac{\partial T_{2}}{\partial x}\right|_{x=0, x_{\max }}=0,\left.\frac{\partial T_{2}}{\partial y}\right|_{y=0, y_{\max }}=0 .
$$

Граничним умовам (3), (4) у рівнянні теплопереносу в грунтовому масиві (1) відповідає відсутність надходження теплоти в розрахункову область з боку ділянок грунтового масиву, розташованих за ії межами. Іншими словами, колектор, розташований в розглянутій розрахунковій області, буде "відбирати" теплоту лише у тій частині грунтового масиву, яка обмежена вказаною областю. При цьому рішення задачі теплопереносу відповідатиме умові найбільш інтенсивного охолодження даної обмеженої ділянки грунтового масиву. Інший варіант завдання граничних умов для даної задачі грунтується на припущенні, що наявність грунтового колектора теплоти не впливає на температурні умови на границях розрахункової області. Це означає, що на iï бічних границях значення температури залежить від часу так само, як у випадку відсутності грунтового колектора. Наприклад, якщо функція $T_{0}(\tau, z)$ описує при- родню сезонну зміна температури грунтового масиву в часі при відсутності колектора в ньому, то граничні умови при функціонуючому колекторі можна сформулювати у вигляді:

$$
\begin{aligned}
& \left.T_{z}\right|_{z=-z_{\text {max }}}=T_{0}\left(\tau,-z_{\max }\right), \\
& \left.T_{z}\right|_{x=0, x_{\text {max }}}=\left.T_{z}\right|_{y=0, y_{\text {max }}}=T_{0}(\tau, z) .
\end{aligned}
$$

Така постановка задачі відповідає максимально можливій інтенсивності надходження теплоти в розглянутій обмеженій ділянці 3 боку зовнішніх шарів грунтового масиву. Результати вирішення даної задачі теплопереносу, при двох розглянутих граничних варіантах постановки граничних умов, будуть збігатися, при збільшенні відстаней від крайніх сегментів теплообмінника до кордонів розрахункової області. Ступінь відмінності вказаних результатів можна вважати критерієм при виборі раціональних розмірів розрахункової області.

Чисельне рішення нестаціонарної задачі теплопереносу в грунтовому масиві при працюючому грунтовому колекторі виявляється достатньо проблематичним внаслідок необхідності використання великої сітки для задачі теплопереносу в грунтовому масиві і дрібної сітки для завдання течії та теплопереносу в каналі колектора. У зв'язку з цим для складання спрощеної розрахункової схеми застосовується ряд припущень. Реальна конфігурація горизонтального грунтового теплообмінника замінюється системою окремих трубчастих сегментів, розташованих один до іншого під прямим кутом (рис. 1). Осі зазначених сегментів вважаються паралельними горизонтальним осях координат. Вхід теплоносія в колектор і вихід з нього визначаються координатами точок перетину осей першого і останнього сегментів грунтового колектора 3 гра-ничною площиною $(y=0)$, які мають значення $x=x_{\mathrm{gx}}, z=-h$ (вхід) i $x=x_{\text {вих }}, z=-h$ (вихід).

Вважається, що течія теплоносія в каналі ламінарна, а профіль ії швидкості - параболічний у всіх його перетинах. Деформацією профілю швидкості на ділянках поворотів каналу нехтуємо. Передбачається також, що температура на зовнішній поверхні стінки циліндричного каналу $\left(R=R_{1}\right)$ рівномірно розподілена по периметрах кіл його нормальних перетинів і змінюється лише по довжині каналу, а профілі температури в каналі - симетричні щодо його осі.

Теплофізичні властивості теплоносія і грунту вважаються постійними. 3 урахуванням зазначених припущень, рівняння теплопереносу в циліндричному каналі колектора набирає вигляду:

$$
c_{\mathscr{N}} \rho_{\varkappa}\left(\frac{\partial T_{\mathscr{K}}}{\partial \tau}+u_{l}(r) \frac{\partial T_{\mathscr{W}}}{\partial l}\right)=\frac{1}{r} \frac{\partial}{\partial r}\left(\lambda_{\mathscr{N}} r \frac{\partial T_{\mathscr{K}}}{\partial r}\right),
$$

де

$$
u_{l}(r)=\frac{2 G}{\pi R_{0}^{2}}\left[1-\left(\frac{r}{R_{0}}\right)^{2}\right] .
$$




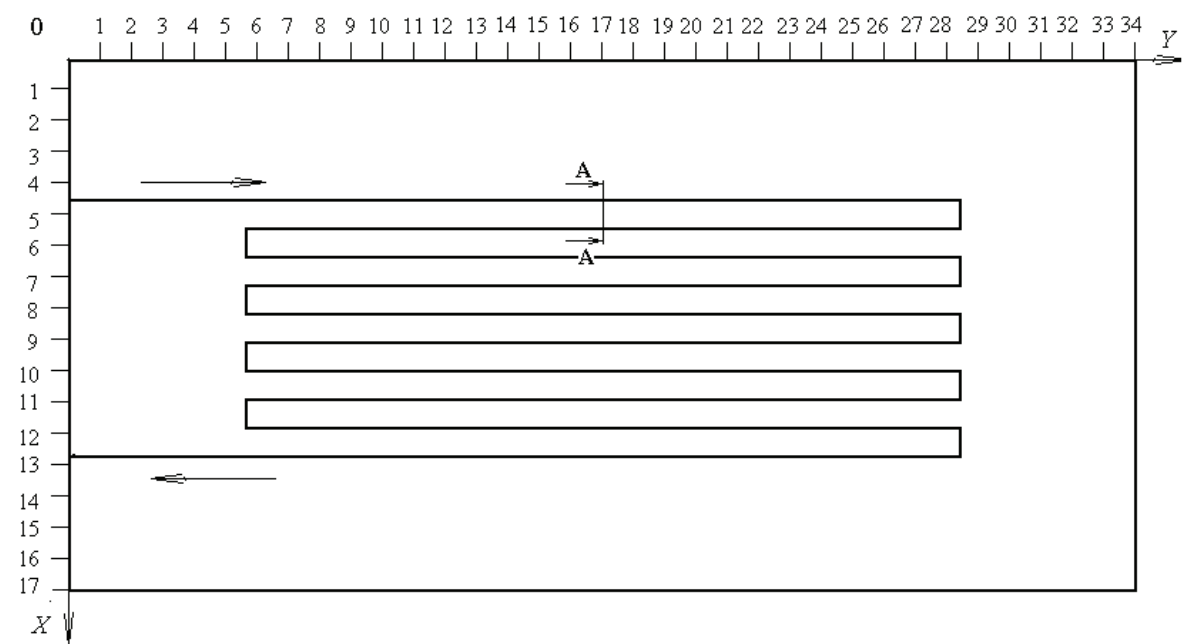

Рис. 1. Горизонтальний переріз розрахункової області на глибині залягання трунтового колектора $(z=1,65 \mathrm{M})$.

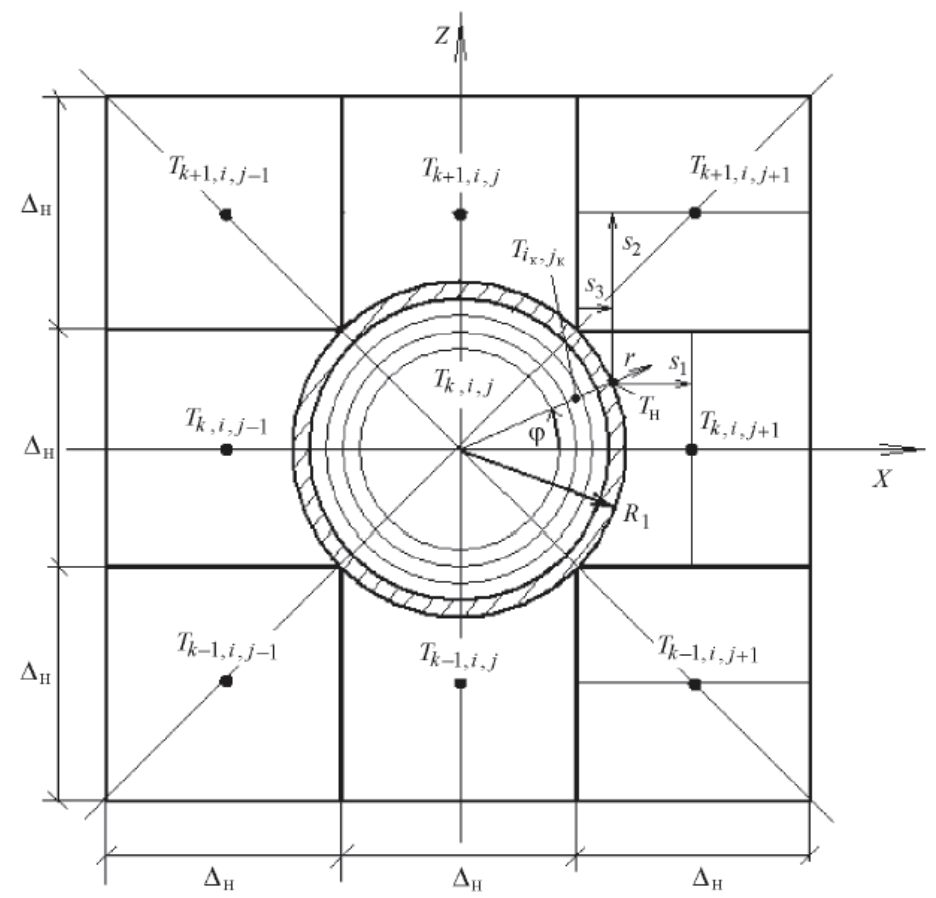

Рис. 2. Фрагмент розрахункової сітки поблизу поверхні каналу.

Якщо вісь каналу паралельна осі $O X$, то

$\frac{\partial T_{\mathcal{H}}}{\partial l}=\frac{\partial T_{\mathcal{H}}}{\partial x}$.

Якщо ж вісь каналу паралельна осі $O Y$, $\frac{\partial T_{\mathcal{H}}}{\partial l}=\frac{\partial T_{\mathcal{H}}}{\partial y}$,

то якщо напрямок течії теплоносія збігається з напрямком осі, i: $\frac{\partial T_{\mathscr{N}}}{\partial l}=-\frac{\partial T_{\mathcal{H}}}{\partial y}$,

якщо напрямок течії теплоносія не збігається з напрямком осі $O Y$.

Температура теплоносія на вході в грунтовий колектор задається відповідно до періодичного режиму роботи теплового насоса. Приймається, що при $l=0 T_{\text {ж }}(\tau, 0, R)=T_{\text {вх }}(\tau)$, де $T_{\text {вх }}(\tau)$ - задана функція. На осі каналу $(R=0)$ приимається умова: 
$\left.\frac{\partial T_{\mathcal{H}}}{\partial r}\right|_{r=0}=0$

Ця умова відповідає осьовій симетрії профілю температури. На внутрішньої і зовнішньої поверхнях стінки каналу задаються умови четвертого роду:

$$
\begin{aligned}
& -\left.\lambda_{\mathscr{H}} \frac{\partial T_{\varkappa}}{\partial r}\right|_{r=R_{0}}=-\left.\lambda_{c} \frac{\partial T_{c}}{\partial r}\right|_{r=R_{0}}, \\
& \left.T_{\mathscr{H}}\right|_{r=R_{0}}=\left.T_{c}\right|_{r=R_{0}} ; \\
& -\left.\lambda_{c} \frac{\partial T_{c}}{\partial r}\right|_{r=R_{1}}=-\left.\lambda_{2} \frac{\partial T_{2}}{\partial r}\right|_{r=R_{1}},\left.T_{c}\right|_{r=R_{1}}=\left.T_{2}\right|_{r=R_{1}} .
\end{aligned}
$$

Припускаючи, що в стінці каналу $\left(R_{0}<r<R_{1}\right)$ перенесення теплоти відбувається лише в радіальному напрямку, то рівняння теплопровідності для цієї стінки можна представити у вигляді:

$$
c_{c} \rho_{c} \frac{\partial T_{c}}{\partial \tau}=\frac{1}{r} \frac{\partial}{\partial r}\left(\lambda_{c} r \frac{\partial T_{c}}{\partial r}\right) .
$$

Початкові умови для поставленої задачі задаються у вигляді $T(0, z, y, x)=T 0(0, z)$. Функція T0 $(0, z)$ характеризує розподіл температури по глибині грунтового масиву в момент початку експлуатації колектора $(T=0)$. Температура теплоносія в каналі колектора, а також температура його стінок вважаються при $\tau=0$ рівними температурі грунту на глибині z $=-h$.

Рівняння теплопровідності для грунтового масиву (зовнішня задача) і рівняння теплопереносу в каналі (внутрішня задача) вирішуються окремо. Узгодження одержуваних рішень здійснюється шляхом задоволення умовами співставлення (12) i (13), заданих на внутрішній і зовнішній поверхнях стінки каналу. Для чисельного рішення рівняння теплопереносу в грунто-вому масиві (1) використовується різницева сітка, що складається $з$ осередків у формі прямокутних паралелепіпедів зі змінними довжинами сторін. Вузли сітки розташовуються в центрах комірок. Форму, відмінну від зазначеної, мають комірки, що безпосередньо примикають до зовнішньої поверхні стінки каналу. Лінійні розміри таких комірок в поперечних перетинах мінімальні і дорівнюють:

$\Delta_{H}=R_{1} \sqrt{2}$.

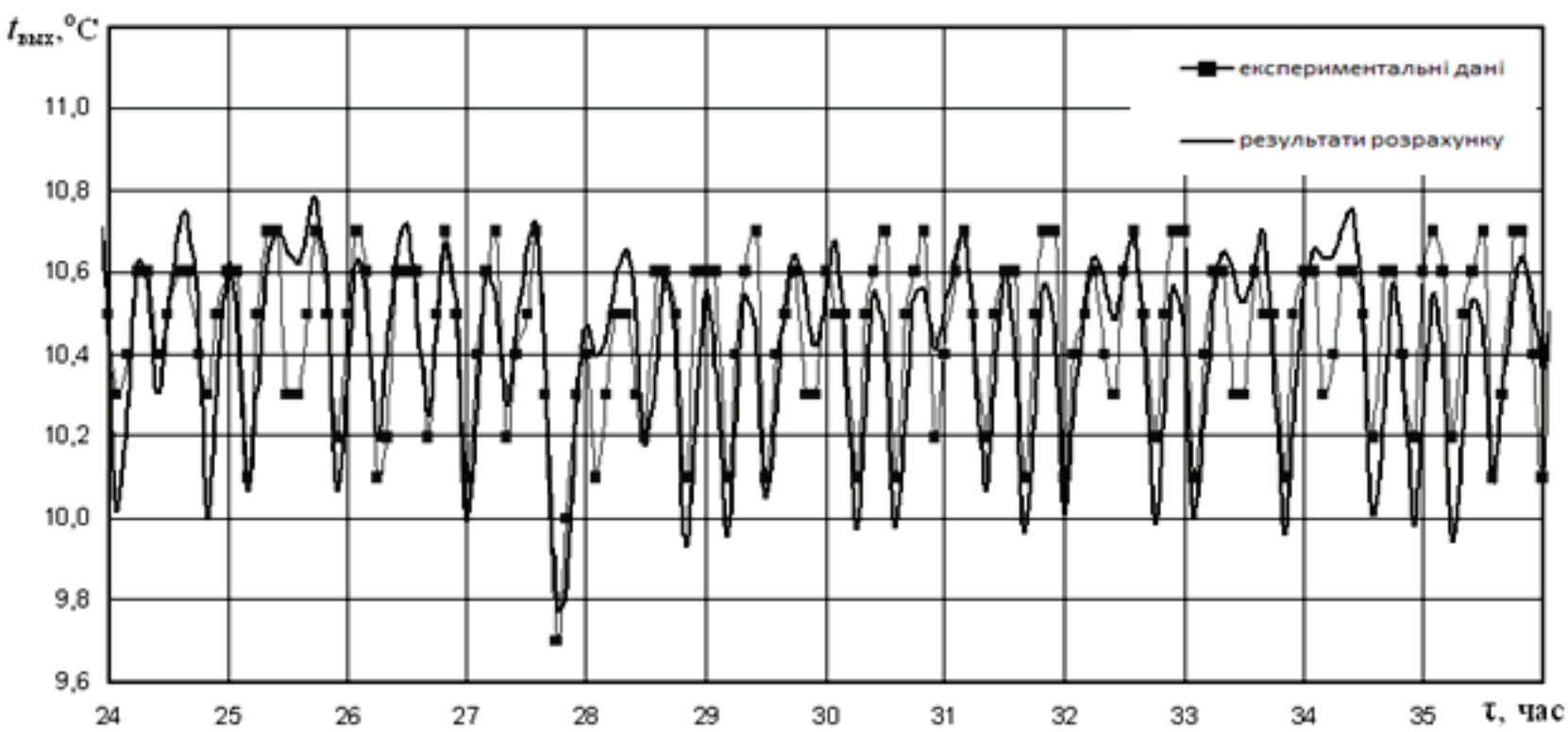

Рис. 3. Зміна температури теплоносія на виході з колектора за період $\tau=24$...36 годин.

Нижче, приводяться результати розрахунків температурного стану горизонтального грунтового колектора. Горизонтальний грунтовий колектор розташований на глибині 1,65 м на території ІТТФ НАН України. Також, приводиться порівняння результатів, отриманих при розрахунках та експериментальних досліджень за допомогою вимірювального комплексу.

3 графіків (рис. 3, 4) видно, що при роботі теплового насоса у поєднанні з горизонтальним грунтовим колектором, температура теплоносія на вході та виході 3 колектора постійно змінюється. Однак, результати розрахунків відповідають експериментальним да- ним. Таким чином, робимо висновок, що дана модель працює адекватно і і1і можливо використовувати для розрахунків горизонтальних грунтових колекторів неглибокого закладення.

На графіках (рис. 5-6) показано розподіл температури в грунтовому масиві. Як видно, при обраному кроці між осями сусідніх труб колектора в 1 м, не відбувається взаємовплив між сусідніми трубами колектора.

Також, був розрахований тепловий потік, що надійшов до теплоносія через горизонтальний грунтовий колектор (рис. 7). Як видно, середнє значення переданого теплового потоку, при роботі колектора складає 3,5 кВт. 


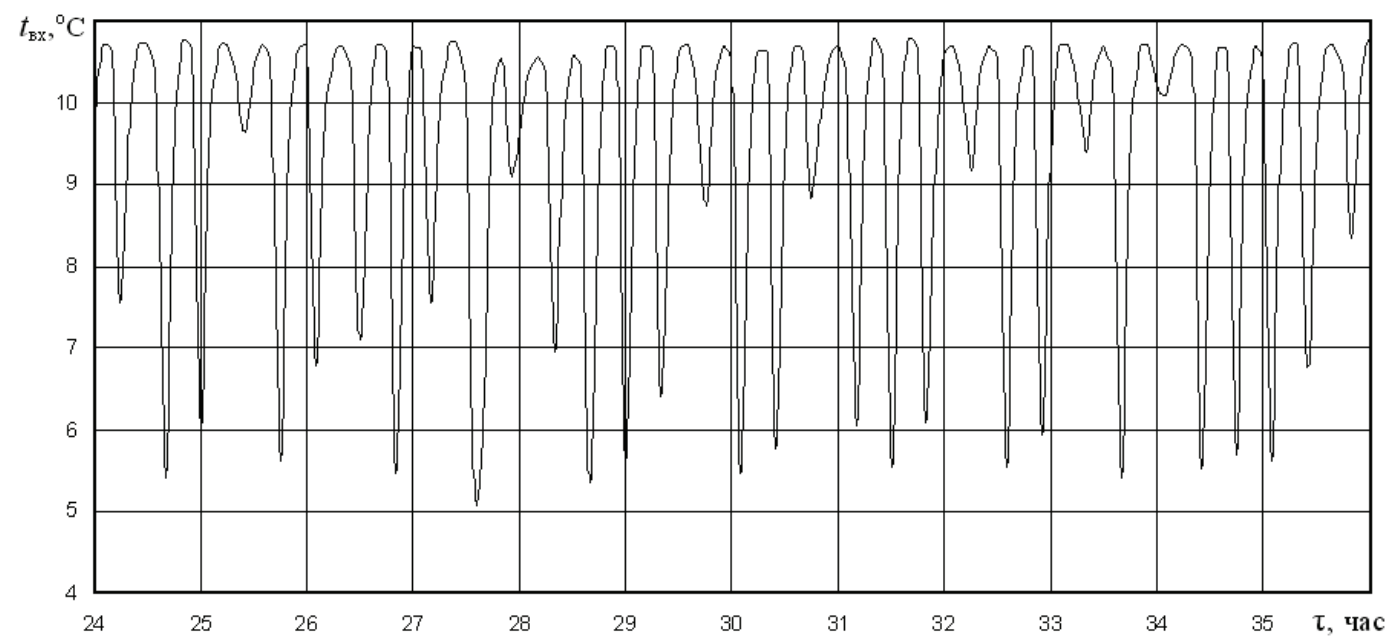

Рис. 4. Розрахована зміна температури теплоносія на вході в колектор за період $\tau=24 . . .36$ годин.

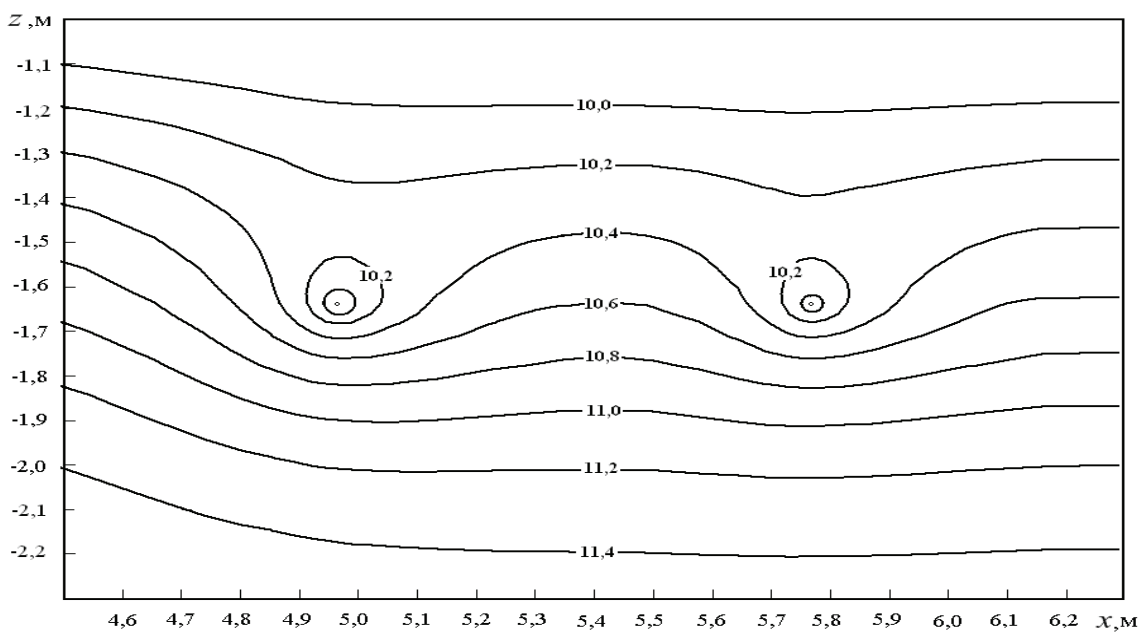

Рис. 5. Розподіл температури у вертикальному перерізі трунтового масиву (розріз $A-A$ (див. рис. 1); $y=17$ м) в момент часу $\tau=54$ годин.

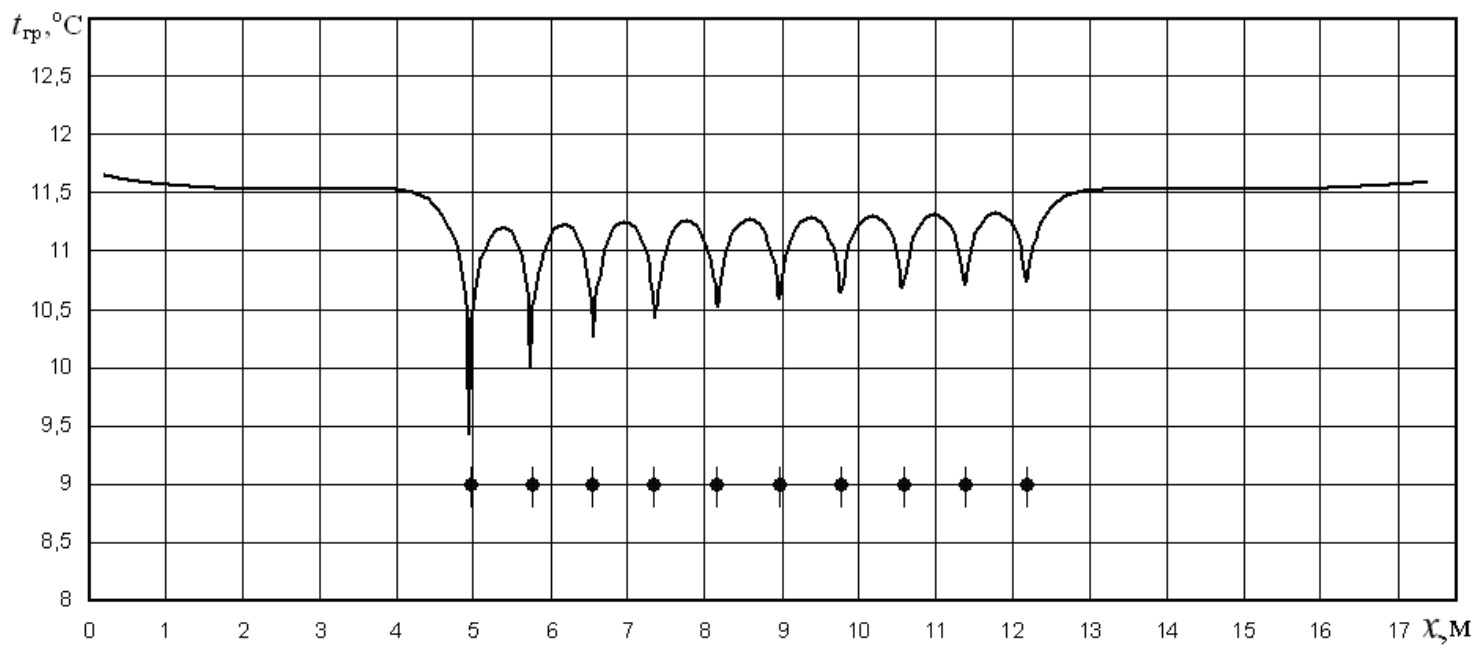

Рис. 6. Зміна температури по ширині грунтового масиву $(z=1,65 . \mathrm{m} ; y=17$ м) в момент часу $\tau=54$ годин. 


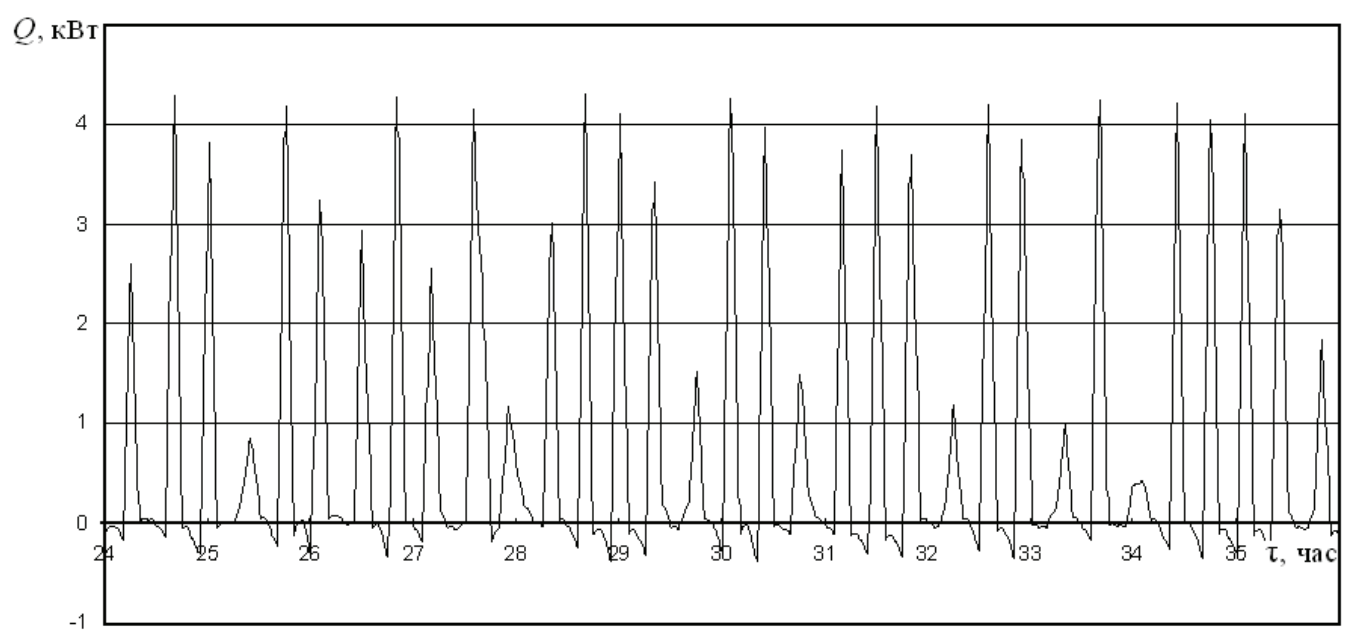

Рис. 7. Зміна теплового потоку, який надійщов до теплоносія за період $\tau=24 . . .36$ годин.

\section{Висновки}

Чисельна модель роботи грунтового горизонтального колектора показала результати, які добре корелюють 3 експериментальними даними [10]. Це свідчить про іiі працездатність.

Встановлено, що крок між осями сусідніх труб $\approx 1$ м, $\epsilon$ оптимальним для вибору їх діаметру та товщини стінки при створенні грунтового колектора в умовах грунту м. Києва (підзолистий грунт). Оскільки при такому кроці мінімізується взаємовплив сусідніх петель грунтового колектора.

Середня розрахункова потужність зняття теплової енергії грунту з 1 погонного метра трубопроводу експериментального ГТО склала 28 Вт.

\section{ЛІТЕРАТУРА}

1. G. Florides. Ground heat exchangers - A review of systems, models and applications / G. Florides, S. Kalogirou. // Renewable Energy. - №32 (2007). - 2007. P. 2461-2478.

2. Безродный M.K. Термодинамічна та енергетична ефективність теплонасосних схем теплопостачання: монографія / Безродный М.К., Притула Н.А. // - Київ: НТУУ «КПІ». - 2016.

3. Мазуренко A.C. Разработка схемы комбинированной системы теплоснабжения с использованием сезонного аккумулирования тепла от гелиосистем/ Мазуренко А.С., Климчук А.А., Юрковский С.Ю., Омеко Р.В. // Восточно-Европейский журнал передовых техноло- гий. - №8 (73). - 2015. С. 17-20.

4. Oussama Ibrahim. Review of water-heating systems: General selection approach based on energy and environmental aspects/ Oussama Ibrahim, Farouk Fardoun, Rafic Younes, Hasna Louahlia-Gualous // Building and Environment.. - Vol. 72. - 2014. - P. 259-286.

5. H. Esen. Numerical and experimental analysis of a horizontal ground-coupled heat pump system / H. Esen M., Inallib, M. Esen // Building and Environment. - №42 (2007). - 2007. - P. 1126-1134.

6. Васильев Г.П. Использование низкопотенциальной тепловой энергии земли в теплонасосных системах/ Васильев Г. П., Шилкин Н. В. // АВОК. - № 2. 2003. С. 52-60.

7. Накорчевский А.И. Оптимальная конструкция грунтовых теплообменников / Накорчевский А. И., Басок Б. И. // Промышл. теплотехника. - Т. 27, № 6. 2005.- C. 27-31.

8. Накорчевский А.И. Технологические показатели различных схем грунтового аккумулирования теплоты / Накорчевский А. И., Басок Б. И., Беляева Т. Г. // Теплоэнергетика. - № 3. - 2006.- С. 29-35.

9. Долинский A.A. Научно-технический центр теплонасосных технологий ИТТФ НАН Украины / Долинский А. А., Басок Б. И., Накорчевский А. И., и др. // Промышл. теплотехника. - Т. 33, № 7. - 2011. - С. 89-91.

10. Басок Б.И. Теплофизика влияния солнечного излучения на здания / Басок Б.И., Накорчевский А.И. // Киев: Наукова думка. - 2016. - 224 с. 


\section{NUMERICAL MODEL OF WORK OF THE HORIZONTAL GROUND COLLECTOR OF HEAT PUMP SYSTEM}

\section{Basok B.I., Nedbaylo A.M., Bozhko I.K.}

Institute of Engineering Thermophysics of the National Academy of Sciences of Ukraine,

2a, Zhelyabova str., Kyiv, 03680, Ukraine

The paper presents a thermophysical numerical model developed at the Institute of Technical Thermophysics of the National Academy of Sciences of Ukraine for studying the processes of hydro-dynamics and heat transfer in a shallow horizontal horizontal collector. The results of verification of this model are given and the main energy indicators of the ground collector operation are calculated.

References 10, figures 7.

Key words: horizontal ground collector; heat pump installation; heat supply system.

1. G. Florides. Ground heat exchangers - A review of systems,models and applications. G. Florides, S. Kalogirou. Renewable Energy. №32 (2007). 2007. P.2461-2478.

2. Bezrodnyiy M.K. Termodinamichna ta energetichna efektivnIst teplonasosnih shem teplopostachannya: monograflya. Bezrodnyiy M.K., Pritula N.A. Kyiv: NTUU «KPI». 2016. (Ukr.)

3. Mazurenko A.S. Razrabotka shemyi kombinirovannoy sistemyi teplosnabzheniya $\mathrm{s}$ ispolzovaniem sezonnogo akkumulirovaniya tepla ot geliosistem. Mazurenko A.S., Klimchuk A.A., Yurkovskiy S.Yu., Omeko R.V. Vostochno-Evropeyskiy zhurnal peredovyih tehnologiy. №8 (73). 2015. P. 17-20. (Rus.)

4. Oussama Ibrahim. Review of water-heating systems: General selection approach based on energy and environmental aspects. Oussama Ibrahim, Farouk Fardoun, Rafic Younes, Hasna Louahlia-Gualous. Building and Environment. Vol. 72. 2014. P.259-286.

5. H. Esen. Numerical and experimental analysis of a horizontal ground-coupled heat pump system. H. Esen M., Inallib, M. Esen. Building and Environment. №42 (2007). 2007. P.1126-1134.

6. Vasilev G.P. Ispolzovanie nizkopotentsialnoy teplovoy energii zemli $\mathrm{v}$ teplonasosnyih sistemah. Vasilev G. P., Shilkin N.V. AVOK. № 2. 2003. P. 52-60. (Rus.)

7. Nakorchevskiy A.I. Optimalnaya konstruktsiya gruntovyih teploobmennikov. Nakorchevskiy A.I., Basok B.I. Promyishl. teplotehnika. T. 27, № 6. 2005. P. 27-31. (Rus.)

8. Nakorchevskiy A.I. Tehnologicheskie pokazateli razlichnyih shem gruntovogo akkumulirovaniya teplotyi. Nakorchevskiy A.I., Basok B.I., Belyaeva T.G. Teploenergetika. № 3. 2006. P. 29-35. (Rus.)

9. Dolinskiy A.A. Nauchno-tehnicheskiy tsentr teplonasosnyih tehnologiy ITTF NAN Ukrainyi. Dolinskiy A.A., Basok B.I., Nakorchevskiy A.I., i dr. Promyishl. teplotehnika. T. 33, № 7. 2011. P. 89-91. (Rus.)

10. Basok B.I. Teplofizika vliyaniya solnechnogo izlucheniya na zdaniya. Basok B.I., Nakorchevskiy A.I. Kyiv: Naukova dumka. 2016. 224 p. (Rus.)

Получено 10.05.2017 Received 10.05.201 